IZA DP No. 10026

Working Conditions and Factory Survival: Evidence from Better Factories Cambodia

Raymond Robertson

Drusilla Brown

Rajeev Dehejia

June 2016 


\title{
Working Conditions and Factory Survival: Evidence from Better Factories Cambodia
}

\author{
Raymond Robertson \\ Texas A\&M University \\ and IZA \\ Drusilla Brown \\ Tufts University \\ Rajeev Dehejia \\ New York University, Tufts University, \\ NBER and IZA
}

Discussion Paper No. 10026

June 2016

IZA

P.O. Box 7240

53072 Bonn

Germany

Phone: +49-228-3894-0

Fax: +49-228-3894-180

E-mail: iza@iza.org

Any opinions expressed here are those of the author(s) and not those of IZA. Research published in this series may include views on policy, but the institute itself takes no institutional policy positions. The IZA research network is committed to the IZA Guiding Principles of Research Integrity.

The Institute for the Study of Labor (IZA) in Bonn is a local and virtual international research center and a place of communication between science, politics and business. IZA is an independent nonprofit organization supported by Deutsche Post Foundation. The center is associated with the University of Bonn and offers a stimulating research environment through its international network, workshops and conferences, data service, project support, research visits and doctoral program. IZA engages in (i) original and internationally competitive research in all fields of labor economics, (ii) development of policy concepts, and (iii) dissemination of research results and concepts to the interested public.

IZA Discussion Papers often represent preliminary work and are circulated to encourage discussion. Citation of such a paper should account for its provisional character. A revised version may be available directly from the author. 


\title{
ABSTRACT
}

\section{Working Conditions and Factory Survival: Evidence from Better Factories Cambodia*}

\begin{abstract}
A large and growing literature has identified several conditions, including exporting, that contribute to plant survival. A prevailing sentiment suggests that anti-sweatshop activity against plants in developing countries adds the risk of making survival more difficult by imposing external constraints that may interfere with optimizing behavior. Using a relatively new plant-level panel dataset from Cambodia, this paper applies survival analysis to estimate the relationship between changes in working conditions and plant closure. The results find little, if any, evidence that improving working conditions increases the probability of closure. In fact, some evidence suggests that improvements in standards relating to compensation are positively correlated with the probability of plant survival.
\end{abstract}

JEL Classification: J8, J5, J3

Keywords: $\quad$ working conditions, apparel, sweatshops, plant survival, closure

Corresponding author:

Raymond Robertson

Bush School of Government and Public Service

Texas A\&M University

4220 TAMU College Station

Texas 77843-4220

USA

E-mail: robertson@tamu.edu

\footnotetext{
* The authors thank without implicating Martin Hess, Ross Jones, Arianna Rossi, Amy Luinstra, Colin Fenwick, Sarah West, two anonymous referees, and participants at the 2011 Better Work Conference for helpful comments and suggestions.
} 


\section{Introduction}

Low wages, long hours, high temperatures, excessive noise, poor air quality, unsanitary conditions, and abuse (both verbal and physical) in developing country manufacturing establishments are often cited as evidence that "sweatshops" characterize production in relatively poor countries. Harsh working conditions in apparel factories are at the center of a large and growing debate about globalization and labor standards (Elliott and Freeman 2003). Several organizations have responded to rising public concern by pressuring governments and employers to improve working conditions. Public exposure, such as anti-sweatshop agitation, seems to have improved working conditions in global supply chains. Harrison and Scorse (2010), analyzing Indonesian manufacturing census data from 1990s, find that workers in the apparel, textile and footwear global supply chains were underpaid relative to workers supplying the domestic sector prior to the anti-sweatshop campaign of the early 1990s, but by 1997 were earning more than the comparison group.

One concern about anti-sweatshop activity is that it imposes constraints on factories that, especially in very competitive environments, may make survival more difficult. Many improvements require costly capital investments (such as air conditioning, plumbing, or safety equipment). Complying with minimum wage laws and providing additional compensation (such as paid leave and overtime) can also increase factory costs. These arguments are trivial to illustrate using even the most basic economic theory: if firms are 
operating efficiently in competitive markets, increases in costs (holding all else constant) will necessarily cause marginal firms to exit. ${ }^{1}$

Factory closings are a considerable concern in developed and developing countries. As a result, there is a sizable literature that seeks to uncover the variables linked to factory survival. Early papers focused on the United States and other developing countries (Bernard and Jensen 2007, Disney et al. 2003, Doms et al. 1995, Baggs 2005, and Greenaway et al. 2008). These papers illustrate the importance of technology, capital intensity, age, and size in survival rates. Recent papers, such as Harris and $\operatorname{Li}(2010)$ find a positive relationship between exporting in particular or exposure to foreign markets generally and survival. Advances in data collection and availability has extended this literature to developing countries, including Ghana, Kenya, and Tanzania (Soderbom et al. 2006), Ethiopia (Shiferaw 2009), Indonesia (Behrman and Deolalikar 1989), and Malaysia (Nor et al. 2007).

These studies suggest that closure is a relevant dimension for analyzing the relationship between improvements in working conditions and apparel factory performance in developing countries. Apparel factories are generally small, have less technology than other sectors, are often recent start-ups, and are considered "footloose" internationally because of the ease at which they close. As a result, apparel factories have much higher closure rates than factories in other sectors (Watson and Everett 1999). It is therefore somewhat surprising that few, if any, of these papers identify underlying driving factors of

\footnotetext{
${ }^{1}$ Reflecting a voluminous literature, Walker (2011), for example, shows that environmental regulation in the United States had adverse consequences for employment. The literature on the effects of labor-market regulations is not as large.
} 
technology that may be improving survival. Fewer still examine the link between changes in human resource practices in general, much less improvements in working conditions.

The goal of this paper is to analyze changes in working conditions in Cambodian apparel exporting factories to see which, if any, are statistically related to the probability of factory closure. Closure is very salient in our sample: about 41 per cent of our firms fail during the sample period. Our data do not include financial information (such as profits), but in the robustness section we explore the relationship between changes in working conditions and employment growth. Changes in compensation compliance is slightly negatively related to employment growth, but no other category of working conditions has a statistically significant relationship.

Our very preliminary results suggest that most dimensions of working conditions are not statistically related to closure: only 3 or 4 of the 31 groups show evidence of a statistically significant relationship (depending on the estimation method and specification). Those that are significant (or nearly significant) tend to be those that are most directly related to worker effort - weekly hours, weekly rest, and payment of wages. Those that are statistically significant are positively correlated with survival. We find very limited, if any, evidence that improvements in any of the areas increase the probability of closure in a statistically or economically important way. These preliminary results seem inconsistent with the argument that improving conditions puts unbearable cost pressure on factories.

In the sections follow, we first describe the BFC program. We then briefly present a broad theoretical framework that guides our analysis. The next section describes the data. The penultimate section presents the empirical results and the final section concludes. 


\section{Better Factories Cambodia}

Cambodia is considered to be a relatively recent example of a successful transformation from central planning to a market-based export-oriented economy. The growth of the apparel sector in Cambodia has played a key role in Cambodia's transformation. Figure 1 shows the rise of Cambodia's exports of apparel to the United States since 2000. Until the financial crisis, U.S. apparel imports from Cambodia rise impressively. As with all imports, the values drop during the crisis (roughly 2008-2010) but demonstrate a considerable recovery afterwards.

Consistent with its status as a low-wage country, Cambodia's apparel exports generally consist of relatively lower-valued products. Low-wage apparel producers, such as Cambodia, are often focal points for concerns about apparel-related human resource practices. Labor-related trade-agreement provisions between the U.S. and several countries are becoming increasingly common. These agreements typically include provisions that require countries to at least enforce national labor law. One early example, the 1999 U.S.Cambodia trade agreement, used increased access to the U.S. market as an incentive for Cambodian firms to improve working conditions (Berik and van der Meulen Rogers 2010). Since apparel trade was restricted by the Multi-Fibre Arrangement (MFA) and the Agreement on Textiles and Clothing (ATC), the promise of such access was believed to be strong enough to induce factories to improve conditions.

To measure such improvements, the Better Factories Cambodia (BFC) was given the task of monitoring factories. The International Labor Organization (ILO) established the BFC program in 2001. Multi-stakeholder participation that includes government, labor, 
factory owners, and international buyers ${ }^{2}$ is a key dimension of the program. In place since 2001, the program strives to improve working conditions with a combination of monitoring, remediation, and training. ILO-trained Cambodian monitors assess the factory's compliance during unannounced visits. The two-person monitoring teams rarely assess the same factory twice in order to minimize monitor bias. The BFC team then compares the results with national law and international standards to develop feedback and suggestions to help factories address concerns. The results are aggregated and presented in annual synthesis report that includes each factory's name and progress on improving working conditions. The BFC program shares these reports with the factories' buyers. Firms were certainly encouraged and perhaps even pressured to improve working conditions using several means. Until 2006, firm-level compliance was made public.

The monitoring reports played a key role in establishing the apparel industry's record of compliance. This record was used by the U.S. government to determine Cambodia's apparel export quota allocation. Many wondered if the loss of the quota incentive after the end of the MFA/ATC would adversely affect factory compliance, but factories continued to comply and improve working conditions after the Arrangement ended. Combining interviews, observations, and BFC synthesis reports, Shea et al. (2010) document sustained increases in working conditions in Cambodia and Beresford (2009) in particular finds that working conditions did not fall in response to an increasingly competitive environment.

The BFC program has captured the attention of many as an example of an innovative way to improve working conditions in global supply chains (Adler and Woolcock 2010,

\footnotetext{
${ }^{2}$ More information about the Better Factories program can be found at http://www.betterfactories.org/.
} 
Beresford 2009, Berik and van der Meulen Rodgers 2010, Miller et al. 2009, Oka 2010a and 2010b, and Polaski 2006). These papers identify several variables that, in the context of the BFC program, are positively related to the factory-level decision to improve working conditions, such as a relationship with a reputation-sensitive buyer (Oka 2010a) and public disclosure of non-compliance (Ang et al. 2012). In the next section we incorporate these and other factors into a general model that identifies some of the relationships between factory characteristics, the BFC program characteristics, and working conditions.

\section{Analytical Framework}

The potential effects of improving working conditions are subtle and potentially conflicting. Working conditions may involve an increase in costs to the firm (such as installing air conditioning or additional plumbing) that may reduce the probability of plant survival for marginal firms. On the other hand, improvements in working conditions may increase worker utility and therefore increase effort or reduce turnover. In this section, we present a simple, original model that illustrates these potential relationships as a way to motivate our empirical work and help interpret the results. In particular, the model also highlights the fact that different kinds of working conditions will have different effects on the factories: those that increase effort will have different effects than those that workers do not value as much. The model also have ambiguous implications for employment because working conditions affect effort. If improving working conditions increases effort, the firm may need fewer workers to achieve production targets.

We begin by assuming that workers maximize utility and factory managers maximize profits subject to market, technology parameters, and information constraints. Firm output is the consequence of worker effort $(e)$ directed at quality $\left(e_{q} \in[0,1]\right)$ and 
quantity $\left(e_{n} \in[0,1]\right)$. Working conditions are characterized by a vector $\left(z_{1} \ldots z_{N}\right)$, for example the rate paid for piece work $\left(z_{1}=w_{n}\right)$, pay based on product quality $\left(z_{2}=w_{q}\right)$, work hours $\left(z_{3}=h\right)$, and other working conditions such as the quality and availability of first aid, the incidence of abuse by factory supervisors, etc.

Workers' bargaining position with regard to the vector of working conditions is determined by maximizing an additively separable utility function of working conditions and work effort. That is, $u=c\left(z_{1} \ldots z_{N}\right)+g\left(e_{q}, e_{n}\right)$. The partial derivatives of $c$ are nonnegative. The partial derivative, $g_{1}$, is negative but the partial, $g_{2}$, may be positive, allowing for the possibility of intrinsic value of work.

The bargaining position of factory managers is derived from the solution of an expected profit maximization program with expected profits given by:

$\pi=p\left(e_{q}\right) \operatorname{Shf}\left(e_{n}, z_{1}, \ldots, z_{N} ; I\right)-\left(w_{n} e_{n}+w_{q} e_{q}\right) h-\sum_{i=4}^{N} a_{i}(I) z_{i}$,

where $p$ is the price of output, $S \geq 1$ is the price premium for meeting a minimum compliance standard, $h$ is hours worked by workers, $e_{n}$ and $w_{n}$ (or $e_{q}$ and $w_{q}$ ) are effort and wages for effort directed at quantity (or quality), $z_{i}$ refers to working condition $i$ and $a_{i}(I)$ its cost as perceived by managers with information set $I$. Firms can compensate for lower effort by hiring more workers (extending hours worked $h$ ). The price, $p()$, depends on the workers' effort with regard to the quality of the product. The production function $f()$ is the factory manager's expectation of hourly output based on the working conditions chosen and is conditional on the factory manager's information set, $I$, concerning production technology.

Factory managers can elicit work effort directed at quality and quantity by paying an efficiency wage or by altering the conditions of work. Factories face an upward sloping effort schedule where the slope depends on the conditions of work. That is 
$e_{q}=e_{q}\left(z_{1}-\bar{w}_{n}, z_{2}-\bar{w}_{q}, z_{3}, \ldots, z_{N}\right)$

$e_{n}=e_{n}\left(z_{1}-\bar{w}_{n}, z_{2}-\bar{w}_{q}, z_{3}, \ldots, z_{N}\right)$

Here we assume that

$\frac{\partial e_{q}}{\partial z_{1}}<0, \frac{\partial e_{q}}{\partial z_{2}}>0$, and $\frac{\partial e_{q}}{\partial z_{3}}<0$

$\frac{\partial e_{n}}{\partial z_{1}}>0, \frac{\partial e_{n}}{\partial z_{2}}<0$, and $\frac{\partial e_{n}}{\partial z_{3}}<0$

That is, incentives targeting quantity reduce effort directed toward quality and vice versa. Increased hours reduce effort toward quality and quantity. The partial derivates of the other working conditions may be positive or negative. Verbal or physical abuse may increase effort on quantity if such treatment is effectively intimidating. However, all working conditions that are perceived by workers as degrading the work environment will reduce effort on quality and quantity. Working conditions that improve information flow will increase effort on quality and quantity. This includes information relating to information about wages and worker grievances.

Working conditions enter the profit-maximization problem at several points. First, the variable $S$ indicates whether the factory is deemed to be in compliance with a minimum working conditions standard, $\bar{s}$, as required by their principal customers or relevant government agent. Here we take $S=1$ if $s\left(z_{1} \ldots z_{N}\right)<\bar{s}$ and $S>1$ if $s\left(z_{1} \ldots z_{N}\right) \geq \bar{s}$.

The size of the compliance premium is increasing in compliance reflecting the degree of reputation sensitivity of a vendor's principal customers. We take low-reputation sensitive buyers to be negatively impacted by BFC generated public report of noncompliance by its vendors. However, such buyers do not consider themselves to be the 
target of anti-sweatshop activism and are, thus, not concerned intrinsically with conditions of work in their vendors.

High reputation-sensitive buyers are concerned both with any noncompliance publically reported by BFC and the potential of an exposé by anti-sweatshop activists. Thus, for the high reputation-sensitive buyer, a record of BFC compliance is, in a sense, infra-marginal. For these buyers, the threat of an exposé exists whether or not BFC is disclosing noncompliance in its vendors.

Working conditions also reflect the HR system employed in the factory. The sign of the partial derivative of the production function, $f$, with respect to a working condition depends on the level of other working conditions and the factory manager's information set, I. (3) The coefficient $a_{i}$ indicates the perceived marginal cost of working condition $z_{i}$ and also depends on the manager's information set, $I$. (4) Working conditions affect the work effort targeting quantity and quality.

Working conditions are the outcome of bargaining between the worker and the firm. The bargaining function is $B=\pi^{\delta} u^{1-\delta}$, where $\delta\left(z_{1}, \ldots z_{N}\right)$ indicates the relative bargaining power of the firm. In the extreme case, $\delta=1$, a factory manager sets working conditions just high enough to satisfy a reservation wage requirement, $u \geq \bar{u}$. We also allow for the possibility that the bargaining power of workers is increasing in the working conditions variables. Improved working conditions, particularly related to two-way communication and positive motivational techniques, may increase a sense of agency on the part of the worker and thereby alter the bargaining parameter.

In our context, the factory manager's information set and perceptions of the partial derivatives of the production function, $f$, with respect to working conditions will be 
augmented by two events. (1) A factory that attempts to come into compliance on a particular point acquires information about the cost and benefits of compliance. (2) Factories may also acquire technical information from its buyer on low-cost strategies on maintaining compliance.

The solution to the firm's optimization problem, then, produces the optimal choice of working conditions at time $t$ and profits that are a function of output prices, minimal acceptable working conditions, the reservation wage and past compliance choices. That is

$$
\begin{aligned}
& \pi^{*}=\pi^{*}\left(\bar{s}, p\left(e_{q}\right), \bar{w}_{n}, \bar{w}_{q}, I, \delta\right) \\
& z_{i t}{ }^{*}=z_{i}{ }^{*}\left(\bar{s}, p\left(e_{q}\right), \bar{w}_{n}, \bar{w}_{q}, I\left(z_{i, t-1}^{*}\right), \delta\right) ; i=1, \ldots, n
\end{aligned}
$$

The introduction of the set of constraints imposed by Better Factories Cambodia altered the information set and market opportunities available to Cambodian apparel manufacturers. Specifically, Better Factories Cambodia enters into the firm's calculus at six points. BFC may alter: (1) the manager's perception of the set of partial derivatives, $f_{2} \ldots f_{N}$, due to a change in the manager's information set, (2) the actual productivity impact of a change in labor practices by improving implementation (similar to that documented by Ichniowski et al. 1997), (3) the manager's perceptions of the cost of a labor practice, $a_{i},(4)$ the capacity of the factory to signal its compliance with a minimum set of labor standards, thereby raising the return to code compliance, (5) the manager's perception of the rigidity with which legal constraints bind on the factory's behavior, and (6) the bargaining position of the factory relative to the worker.

Assuming that managers are optimizing with full information and without perceptions of coordination failures, the regulations imposed by the BFC program should increase the rate of factory failure (closure) because if they do not affect effort, increases in 
costs (due to increasing compliance) reduce profits. Given the competitive environment, an increase in costs induced by the program should push marginal firms past the breaking point and cause them to fail. On the other hand, if the measures help the firm, perhaps by increasing worker effort or productivity, then the chances of firm survival may increase. In addition, the effects on employment (the infra-marginal measure) are also ambiguous. Increases in effort that may come from improving working conditions may mean that fewer workers are necessary to reach production targets. Furthermore, the model demonstrates that improvements in different categories of working conditions should have different effects. Categories that are most valued by workers, or, in the context of the model, most directly affecting worker effort, are most likely to exhibit a positive correlation with survival. Those that increase costs without increasing productivity (e.g. through effort), are more likely to be associated with plant closings. We evaluate these statistical relationships in the following sections.

\section{Data}

This paper uses factory-level monitoring reports matched with factory-specific information. Factory-specific information includes ownership, unions, dates of monitoring visits, location, and, of course, results from individual questions about working conditions in the factory. Participation is mandatory for all exporting factories. We take the integrity of the compliance reports at face value. While it would be naïve for us to suggest that these, or any compliance reports anywhere in the world, are completely immune from corruption, several sources cite the ILO and IFC involvement has providing higher integrity than might 
otherwise be expected. Kotikula et al. (2015) provide a more complete discussion of the evolution of the Better Work program.

The 2001-2002 wave of visits included 119 factories. For the next three years monitors focused on specific concerns identified in the initial reports and did not complete full monitoring reports. As a result, factory-level data are unavailable for the 2003-2005 period. An improved Information Management System (IMS) survey initiated the next wave of documented visits in December 2005. Since 2005, the BFC has maintained a goal of visiting factories about every eight months, but, in practice, some factories were visited once per year.

Table 1 shows the number of factories by visit by year. The available data span the 2001-2010 period. As expected, the table's upper triangular structure shows new firms entering each year (with a first visit) and existing firms accumulating visits. The 446 individual factories identified in our data generate a total of 2,113 total observations with the maximum number of visits observed for any factory being 10 . The vast majority of the sample (93.7\%) is foreign-owned, with $42 \%$ owned by China, Hong Kong SAR, and Macau SAR, 23.3\% owned by Taiwan, and less than 3\% owned by Western countries.

Since the main focus of this paper is factory closures, it is important to identify factories that have actually closed rather than simply changed names (Watson and Everett 1999). We address this in two ways. First, the BFC program maintains a list of factories that they have confirmed to have actually closed. We use this list as our primary indicator of factory closings. As a secondary check, we compare the addresses of the factories over time. Fewer than five have the same address with distinct names. We use the same factory identifier for factories with the same address but with different names. It is possible, of 
course, that factories close and then re-open at another location with a different name and different ownership (e.g. Macau SAR may have a factory that closes and passes its business to a firm owned by mainland China), and we treat these as separate factories.

Table 2 contains the operating status (defined as whether or not the factory closes at some point in the sample) by operating country. The first point is that about $41 \%$ of the factories with a first visit close during the sample period. Closure rates are highest for those countries that had very few factories associated with them. This result may indicate that these countries are less committed to Cambodian production and therefore provide fewer resources that may be associated with survival, or there may be weaker supply-chain links between these countries and Cambodia due to distance or other barriers. The financial crisis also seems to have significantly increased factory closures. Figure 2 shows factory closures by month during the sample period. The crisis period, roughly $2008-2010$, shows a significant increase in closures relative to the earlier period. Even as exports recover, however (as illustrated in Figure 1), Figure 2 suggests that closures remain high.

Factory monitors use a tool that includes 405 specific questions designed to cover the gamut of working conditions. These questions are coded with a binary variable in which the value 1 indicates compliance and 0 indicates non-compliance. Sixty-two of the 405 questions show no variation across both factory and visit and therefore are dropped from the analysis. We aggregate the remaining questions into 31 categories that are listed in Table 3. Table 3 also includes the average compliance at the first visit, which is calculated by first taking the simple (unweighted) average of all binary compliance indicators within each group for each factory and then taking the average of each category across all factories. 
Table 3 shows significant variation across category first-period averages. Firms are almost universally compliant (99.7\%) with forced labor standards, which is not surprising since this is widely considered to be an extremely serious violation. At the other extreme OSH (Occupational Safety and Health) Assessment/Recording/Reporting has a much lower compliance average of just over $59 \%$.

It is interesting to note that sexual harassment also has extremely high compliance, which may reflect the difficulty of accurately capturing cases. This is especially true in countries with a limited history of legislation protecting women from workplace harassment. A 2006 United Nations report notes that "Regardless of data collection procedures, the actual number of women who experience sexual harassment is likely to exceed by far the number of reported cases" (United Nations 2006, p. 68).

One characteristic of our working conditions measures is that the most significant improvements in working conditions generally occur between the first and second visits (Ang et al. 2012). Therefore, Table 3 also includes the change in the average across the first and second visits. Not surprisingly, the largest changes occur in those areas with the lowest levels of compliance in the first visit. Although not demonstrated here, we also note improvement generally follows a similar pattern across the categories: the largest improvements occur between the first and second visits and the absolute magnitude of improvements falls (but generally remains positive) as the number of visits increases.

The factory-level data are then arranged to facilitate survival analysis. The first relevant assumption for the data construction involves exposure to risk. We have no data prior to the BFC program. In particular, we have no factory-level data prior to the BFC program. Therefore, we make the assumption that the risk-exposure period corresponds to 
the BFC period. In doing so, we are therefore evaluating the exposure to the BFC "treatment" on survival probabilities using visits as our measure of time. As will be evident below, we control for the financial crisis in our formal estimation.

\section{Analysis}

The analytical framework suggests that improvements to working conditions that do not increase worker effort should be correlated with plant failure. Different categories of working conditions may have different effects. To begin to estimate the correlations between changes in different categories and plant failures, we begin by describing survival analysis, which has been increasingly applied in situations similar to that studied in this paper (e.g. Harris and Li 2010).

\section{Survival Analysis}

One of the first steps in survival analysis is to analyze the Kaplan-Meier survival function. Figure 3 shows that the Kaplan-Meier survival estimate falls with the number of visits. Apparel manufacturing, especially at the lower end of the value chain, is risky. Turnover is high: factory births and deaths are common. Figure 3 reflects this by showing the chances of survival fall through time.

One way to evaluate whether or not improvement in working conditions affects survival is to compare the survival probability conditional only on whether or not factories increased compliance prior to closing (or the end of the sample). Disaggregating KaplanMeier survival functions between factories that improved compliance between the first and second visit for various compliance areas, as shown in Figure 4, suggests that factories that 
increased compliance had higher survival rates. We test with result more formally using logrank tests of equality of survival functions for each of the 31 compliance groups. There are few, if any, categories in which improvements are associated with a higher probability of closure. That said, however, only two categories (Payment of Wages and Emergency Preparation) have statistically significant effect on survival probabilities. Improvements in most categories do not have statistically significant relationships with survival.

In addition to the lack of a relationship, several other possibilities might explain the relative lack of significance between the survival functions. Factories that made large changes between the first and second visit may have little room for improvement left for future visits. If these factories survive longer, then the contemporaneous change in working conditions may have little to do with the probability of survival in any given period. Therefore, we also test the differences in survival functions based on whether or not the factory made improvements in a given category between the first and second visits. Many more areas with differences are statistically significant, suggesting that the initial improvements affect later survival. Several statistically significant categories are associated with compensation, notably payment of wages, regular hours/weekly rest, and contracts. Others tend to be associated with occupational safety and health and workplace operations.

\section{Proportional Hazard Estimation}

Of course, these unconditional comparisons do not control for other factors that might affect survival. To analyze survival probabilities more formally, we follow Harris and Li (2010), Esteve-Pèrez et al. (2004), Disney et al. (2003), and others and employ the Cox (1972) proportional hazards model. Two of the main advantages of the Cox estimation 
approach is that it is quite straightforward and it is robust to various (all) specifications of the baseline hazard. It is therefore considered to be the main workhorse of survival analysis.

To save space the results are not presented, but very few of the 31 compliance category estimates are statistically significant. In levels, drinking water, food, and emergency preparedness are significant at the 5\% level, and all of these are negative (meaning higher levels are associated with lower probability of closure). In differences, the sign switches for emergency preparedness, suggesting that larger improvements in this area are associated with a higher probability of failure. The only other statistically significant result in differences is for regular hours/weekly rest, which has a relatively large negative coefficient, suggesting that improved compliance in regular hours regulations increases the probability of survival. Focusing on just the change between the first and second visit generates no statistically significant coefficients. When focusing on those firms that improved between the first and second visit, however, the results suggest that second-visits improvements in wage payments are associated with lower probability of failure. None of the other estimates are statistically significant and the estimates are generally small.

This approach allows us to control for other factors that have been shown to affect survival, such as firm size and ownership (Harris and Li 2010). These both matter. Large firms (when measured by the log of total employment) are less likely to close. Region of ownership is not statistically significant.

Two measures that are consistently important - both economically and statistically are the crisis period (equal to one after mid-2008) and being associated with a reputationsensitive buyer. Oka (2010a and 2010b) finds that a reputation-sensitive buyer is important for factory compliance, and there may be additional effects here too on the probability of 
survival. Reputation sensitive buyers may support their factories with higher prices in exchange for improvements in working conditions that might improve the reputations of the buyers. Of course, the crisis period is strongly associated with higher probability of failure.

The main message, however, is few of the individual categories are statistically significant. There is very little, if any, evidence that improving working conditions reduces the probability of survival. One possible concern about these results, however, is that factories may take strategies to improve working conditions in particular areas together. In fact, the changes in individual categories are highly correlated, and these correlations may mask underlying factors - such as implementation costs - that drive the decisions about compliance.

\section{Factor Analysis}

To analyze the possibility of common underlying factors, we turn to factor analysis. The goal of factor analysis is to find a few common factors that might be driving changes of individual categories and thereby reduce the number of variables considered by forming linear combinations of the underlying categories into meaningful groups. One important concern about factor analysis is that the groupings are admittedly subjective, and therefore we explain our steps carefully.

We begin by performing a factor analysis for the 31 compliance categories using the principle-factor method. One alternative possibility would be to employ the principlecomponents factor method. This approach assumes that the commonalities are equal to one. The problem in our case with this approach is that assuming that the commonalities are equal to one is equivalent to assuming that the uniqueness (the proportion of the variation in 
the categories explained by the underlying factors) is equal to zero. The average of our uniqueness estimates is just over 0.65 . Given that the uniqueness values are so high, the principle components analysis is probably not appropriate.

We perform the principle-factor method on 28 of the 31 categories. The first threechild labor, forced labor, and discrimination - correspond to the core labor standards. These also start with generally high compliance and vary little, so we put them into a separate group and perform the factor analysis on the remaining 28 categories.

We then perform an orthogonal rotation on the results to generate Table 4. The factor analysis identifies nine possible factors. The maximum values of each row (category) are shown in bold. Note that none of the maximum values appear in factors 6 and 8 , so we focus our attention on the remaining factors. Although subjective, it appears that a meaningful pattern emerges from the pattern of results in Table 4 . We use these results to sort the 31 categories into the 5 groups shown in Table 5. As mentioned, these involve a combination of subjective judgment and interpretation of the results in Table 4 .

The next step is to replace the individual categories with the 5 factors (the core labor standards are excluded for the same reasons described above) into the Cox estimation. These results are shown in Table 6 . Table 6 contains four columns. Column 1 uses the mean levels of the working conditions groups. Column 2 uses the changes between visits. Column 3 uses the change between the first and second visit. Column 4 uses an indicator variable equal to one if the factory improved compliance in this category between the first and second visit.

As with the individual categories coefficients, the majority of the estimates are not statistically significant. The only variables that are statistically significant at the $5 \%$ level 
(OSH in column 1 and Communication, Modern HR, and Compensation in Column 4) are negative, suggesting that these improvements increase the changes of factory survival. Compensation in column 1 , statistically significant at the $10 \%$ level, is positive, but this result reverses in columns (2), (3), and (4). This is the only potential evidence suggesting that higher compliance increases the probability of factory failure, and is probably worth continued investigation.

Total employment and being linked to a reputation-sensitive buyer increase the probability of survival, while the crisis period (2008-2009) is strongly associated with closure, which is consistent with Figure 2. Also consistent with Figure 2 is the fact that even during the period in which imports recover (years after 2009), closures remain high. The estimated coefficient on the "recovery" variable is just slightly lower than the estimated coefficient for the crisis period, suggesting that the increase in imports was not immediately transmitted into higher survival probabilities for factories. Ownership does not seem to have a significant effect, and we explore this in more detail further into the paper.

It is probably important not to put too much emphasis on the statistically significant negative coefficients for working conditions measures in Table 6. These do not appear to be robust to the inclusion of other variables, such as the number of unions. The main message from these results should probably be that there is surprisingly little, if any, evidence that improvements in working conditions increase the probability of factory closure.

One additional concern that arises from Table 6 is that that foreign ownership does not have a statistically significant effect on closure. ${ }^{3}$ The result contrasts with most previous research of factory closure that finds foreign ownership generally increases

\footnotetext{
${ }^{3}$ In additional unreported results, we collapse all foreign ownership into a single dummy variable and try alternative groupings of countries. These variables are also statistically insignificant in the survival analysis.
} 
survival. One possibility is that the disaggregated country groups hide an overall distinction between domestic (Cambodian) and foreign factories. Table 7 shows the results of including a single control (equal to one) for foreign factories. This variable is never statistically significant, and the rest of the results remain qualitatively similar. In particular, column (4) shows that second-visit changes in several of the working conditions are associated with a lower probability of closure (higher probability of survival).

Another possibility is that foreign ownership may proxy for international support and commitment to factories, or may reflect value chain relationships (upstream and downstream). To explore the possibility that the number of other firms of the same nationality affect survival, ${ }^{4}$ we include this variable directly in place of the foreign ownership controls. These results are shown in Table 8. In three of the four columns, the number of other factories with the same ownership is statistically significant and has a consistently negative sign. These results suggest that support networks may matter in the sense that having more factories of the same nationality may increase the chance of survival. These results may also alternatively suggest that the number of factories with the same ownership reflects better market opportunities (such as stronger value chain links). Understanding these differences may be a valuable direction for future research.

\section{Robustness}

There are several dimensions in which we explore the robustness of the results. The first is to omit the crisis. The crisis controls that are included in the earlier tables may not sufficiently control for the crisis. Table 9 contains the results when the crisis period is

\footnotetext{
${ }^{4}$ We thank Martin Hess and Ross Jones for this suggestion.
} 
excluded from the sample. If anything, the results now suggest that the correlation between changes in working conditions and the probability of survival becomes stronger in the sense that now three of the five groups have statistically significant coefficients (communication, modern HR, and compensation).

Another concern is that factories that have higher initial compliance may have less room to improve and may be more likely to survive. If so, then incompletely controlling for initial compliance would bias the results towards zero. This argument is especially salient for the new entrants. New entrants may learn from the experiences of previous entrants and, presumably, adjust their starting levels of compliance in response to lessons learned from previous entrants. Kotikula et al. (2015) show that first-visit noncompliance rates fall over time. Note that this argument presumes that good working conditions are correlated with survival, which runs counter to the presumption that improving working conditions imposes disadvantageous cost increases.

To address these arguments, Table 10 contains the results in which the initial compliance levels are included along with the changes in columns (2)-(4). The initial compliance level coefficients are omitted to save space. As when the crisis period is excluded, controlling for initial compliance levels generates statistically significant results that suggest that improvements between the first and second periods are correlated with lower probabilities of closure (higher probabilities of survival).

As another robustness check, we also explore the relationship between changes in working conditions and changes in employment (measured as the log difference of total employment between visits). Employment changes are on average rather small (less than 5\%). Table 11 contains the analog to columns (1) and (4) from the previous tables. The 
results suggest that with the exception of modern $\mathrm{HR}$, the coefficients are either negative and small or positive and not statistically significant. Modern HR is negative and significant, suggesting firms with initially higher levels of modern HR compliance have smaller changes in employment over time.

When considering the improvements in working conditions between the first and second visit in column (2) we see only compensation is statistically significant and negative. Presumably, these firms are paying higher wages and may be making a trade-off between having fewer workers who earn more. It is also interesting that being associated with a reputation-sensitive buyer, shown to be positively correlated with other positive firm characteristics and outcomes, is negative and statistically significant. To explore this further, figure 5 shows the distributions of employment changes for firms that improved compensation compliance between the first and second visit. Figure 5 shows that, while the change in employment is lower, the variance is lower for firms that improved working conditions in this area. Worker turnover is often cited as a significant cost for firms, and figure 5 suggests that firms that improved compensation may have a lower variance in employment (that is, less turnover), and therefore may have realized cost savings that could possibility help explain the positive correlation between improvements in this area and the increased probability of survival, but the causality is not definitely established here.

\section{Conclusions}

Rather than being associated with widespread failure of Cambodian factories, the BFC program has been lauded as a success. Improvements in working conditions have been associated with rising exports, wages, and employment. The results in this paper suggest that, contrary to even very basic economic models, there is little evidence that 
improvements in working conditions have imposed burdens great enough to cause them to shut down.

One possible explanation for the relative lack of adverse effects is that improving some working conditions is more likely to be positively associated with survival. If factories have full information, then the finding of a positive relationship between working conditions and survival (which is more prevalent in our results than support for a negative relationship), would suggest that improving working conditions is a good decision that is made by good managers. At the same time it is possible that factories that expect to close (perhaps due to other poor decisions) may refrain from making the investments. Emerging results, such as Bloom et al. (2013), however, suggest that developing country factories do not have full information and that it is likely that the external emphasis on improving working conditions induced policy experimentation.

Another possibility is that the positive relationship has roots in an "efficiency wage" explanation that dates back to Alfred Marshall. This seems particularly possible given the fact that the statistically significant negative coefficients (that suggest that improvements reduce the probability of closure) tend to relate to compensation and modern HR practices. Worker incentives may be associated with higher productivity, which might increase profits for the firm is productivity increases more than compensation (broadly defined). Future work on programs that improve working conditions should therefore focus on the link between worker and factory output and working conditions. 


\section{References}

Adler, Daniel, and Michael Woolcock (2010) "Justice without the Rule of Law? The Challenge of Rights-Based Industrial Relations in Contemporary Cambodia" In Human Rights at Work: Perspectives on Law and Regulation, ed. Colin Fenwick and Tonia Novitz. Oxford: Hart Publishing.

Álvarez, Roberto and Sebastián Vergara (2010) "Exit in Developing Countries: Economic Reforms and Plant Heterogeneity" Economic Development \& Cultural Change; 58(3) (April), pp. 537-561.

Ang, Debra, Drusilla Brown, Rajeev Dehejia, Raymond Robertson (2012) "Labor Law Compliance and Human Resource Management Innovation: Better Factories Cambodia" Review of Development Economics 16(4), (November): 594-607.

Baggs, Jen (2005) "Firm Survival and Exit in Response to Trade Liberalization" Canadian Journal of Economics 38(4) (November), pp. 1364-83.

Behrman, Jere R., and Anil B. Deolalikar (1989) “... Of the fittest? Duration of survival of manufacturing establishments in a developing country" Journal of Industrial Economics 38(2) (December), pp. 215-226.

Beresford, Melanie (2009) "The Cambodian Clothing Industry in the post-MFA Environment: A Review of Developments" Journal of the Asia Pacific Economy 14(4) (November), pp. 36688.

Berik, Günseli and Yana van der Meulen Rodgers (2010) "Options for Enforcing Labour Standards: Lessons from Bangladesh and Cambodia" Journal of International Development 22, pp. 5685.

Bernard, Andrew, and J. Bradford Jensen (2007) "Firm Structure, Multinationals, and Manufacturing Plant Deaths" The Review of Economics and Statistics" 89(2) (May), pp. 193-204.

Bloom, Nicholas; Benn Eifert, Aprajit Mahajan, David McKenzie, and John Roberts (2013) "Does Management Matter? Evidence from India" The Quarterly Journal of Economics 128 (1), pp. 1-51 first published online November 18, 2012doi:10.1093/qje/qjs044

Cox, David R (1972) "Regression Models and Life-Tables" Journal of the Royal Statistical Society. Series B (Methodological) 34(2), pp.187-220.

Disney, Richard, Jonathan Haskel, and Ylva Heden (2003) "Entry, exit and establishment survival in UK manufacturing" Journal of Industrial Economics 51(1) (March), pp. 91-112

Doms, Mark, Timothy Dunne, and Mark J. Roberts. 1995. The role of technology use in the survival and growth of manufacturing plants. International Journal of Industrial Organization 13, (4) (December 1995): 523-542

Elliott, Kimberly Ann and Richard B. Freeman (2003) Can Labor Standards Improve under Globalization? Institute for International Economics, Washington, D.C.

Esteve Pérez, Silviano, Amparo Sanchis Llopis, and Juan Alberto Sanchis Llopis (2004) "The Determinants of Survival of Spanish Manufacturing Firms" Review of Industrial Organization 25(3), pp. 251-73.

Greenaway, David; Joakim Gullstrand, and Richard Kneller (2008) "Surviving Globalisation" Journal of International Economics, 74(2), pp. 264-77.

Harris, Richard I.D. and Qian Cher Li (2010) "Export-Market Dynamics and the Probability of Firm Closure: Evidence for the United Kingdom" Scottish Journal of Political Economy 57(2), (May), pp 145-168.

Harrison, Ann E. and Jason Scorse 2010 "Multinationals and Anti-Sweatshop Activism"American Economic Review, 100(1), pp. 247-73.

Ichniowski, Casey, Kathryn Saw and Biovanna Prennushi. (1997) "The Effects of Human Resource Management Practices on Productivity: A Study of Steel Finishing Lines.” American Economic Review 87(3), pp. 291-313, June. 
Kotikula, Aphichoke; Milad Pournik; and Raymond Robertson (2015) Interwoven: How the Better Work Program Improves Job and Life Quality in the Apparel Sector World Bank Group, Washington D.C.

Miller, Doug, Vaasna Nuon, Charlene Aprill, and Ramon Certeza (2009) "Business as Usual? Governing the Supply Chain in Clothing - Post MFA phase-out: The case of Cambodia" International Journal of Labor Research, 1(1), pp. 10-33.

Nor, Norashidah Mohamed, Nor, Nor Ghani M, Ahmad Zainuddin Abdullah, and Suhaila A. Jalil. (2007) "Flexibility and small firms' survival: Further evidence from Malaysian manufacturing" Applied Economics Letters 14, (10-12) (August-October 2007): 931-934.

Oka, Chikako 2010a "Accounting for the Gaps in Labour Standard Compliance: The Role of Reputation-Conscious Buyers in the Cambodian Garment Industry” European Journal of Development Research 22(1): 59-78.

Oka, Chikako 2010b "Channels of Buyer Influence and Labor Standard Compliance: The Case of Cambodia's Garment Sector" Advances in Industrial and Labor Relations 17: 153-183.

Polaski, Sandra (2006) "Combining Global and Local Forces: the Case of Labor Rights in Cambodia." World Development 34(5), pp 919-32.

Shea, Anna, Mariko Nakayama, and Jody Heymann (2010) "Improving Labor Standards in Clothing Factories" Global Social Policy 10(1), pp. 85-110.

Shiferaw, Admasu. (2009) "Survival of private sector manufacturing establishments in Africa: The role of productivity and ownership" World Development 37(3) (March), pp. 572-584

Soderbom, Mans, Francis Teal, and Alan Harding (2006) “The determinants of survival among African manufacturing firms" Economic Development and Cultural Change 54(3) (April), pp. $533-555$

United Nations (2006) "In-depth study on all forms of violence against women" Report of the Secretary-General, Sixty-first session. Item 60 (a) of the preliminary list*. Advancement of women: advancement of women. Available at "http://stopvaw.org/sites/3f6d15f4-c12d4515-8544-26b7a3a5a41e/uploads/Sec_Gen_Study_VAW.pdf."

Walker, W. Reed (2011) "Environmental Regulation and Labor Reallocation: Evidence from the Clean Air Act" American Economic Review 101(3), (May), pp. 442-447.

Watson, John and Jim Everett (1999) "Small Business Failure Rates: Choice of Definition and Industry Effects" International Small Business Journal 17(2), pp. 31-47. 
Figure 1: U.S. Apparel Imports from Cambodia (Constant U.S. Dollars)

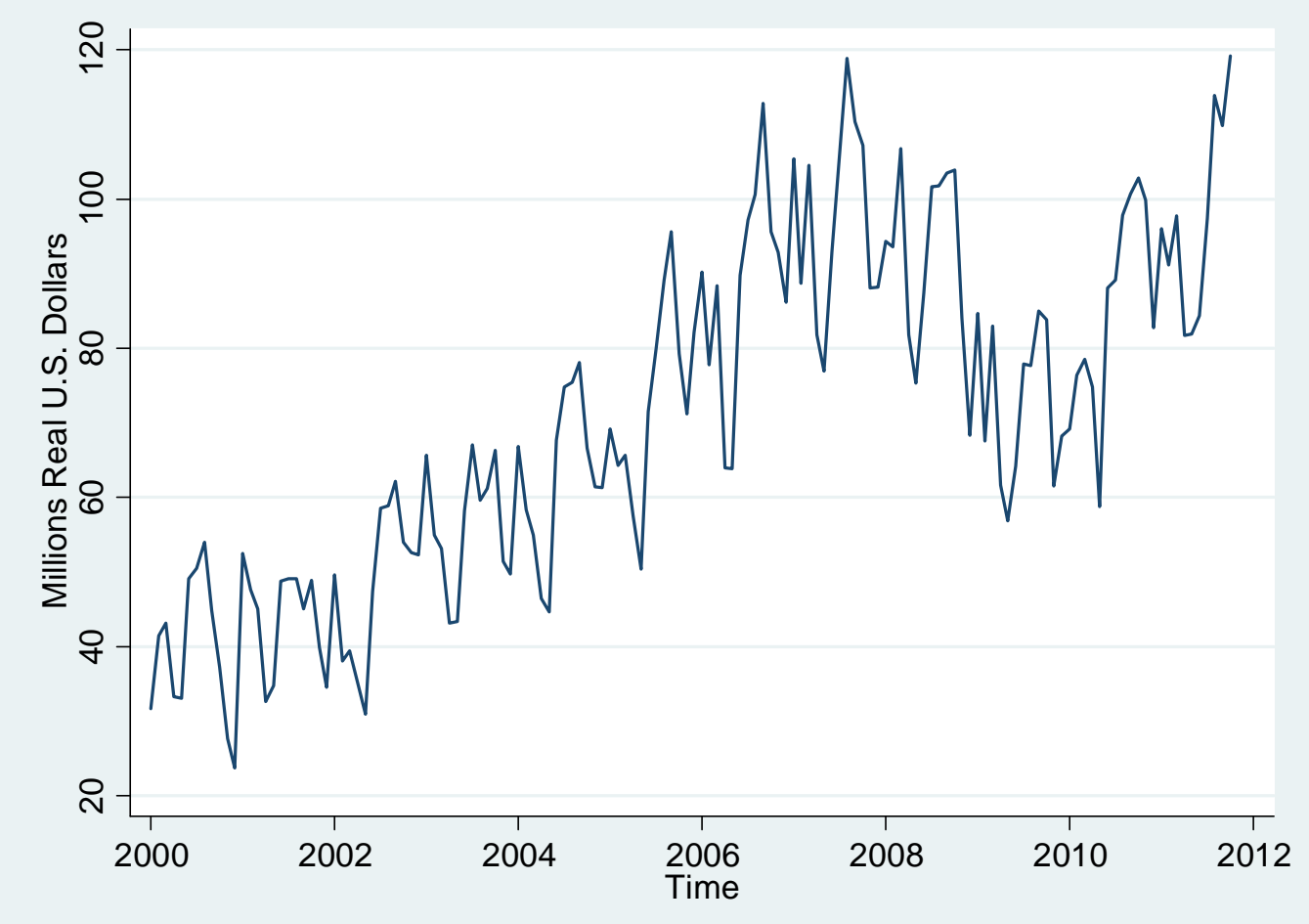


Figure 2: Post 2005 Closures by Closing Month

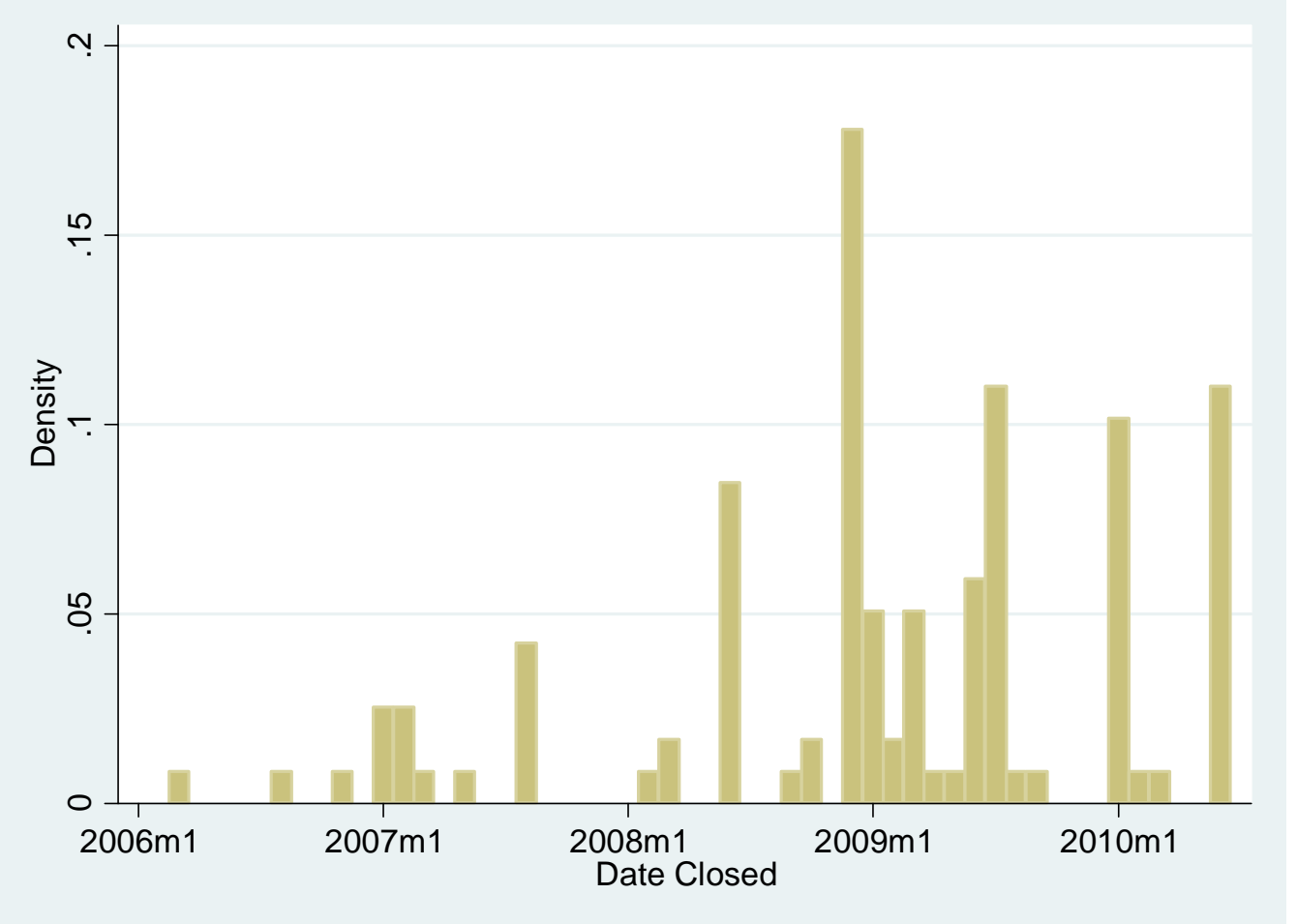

Notes: Graph excludes factories that did not close during the sample period. The horizontal axis is measured in months. 
Figure 3: Survival Estimate (All Factories)

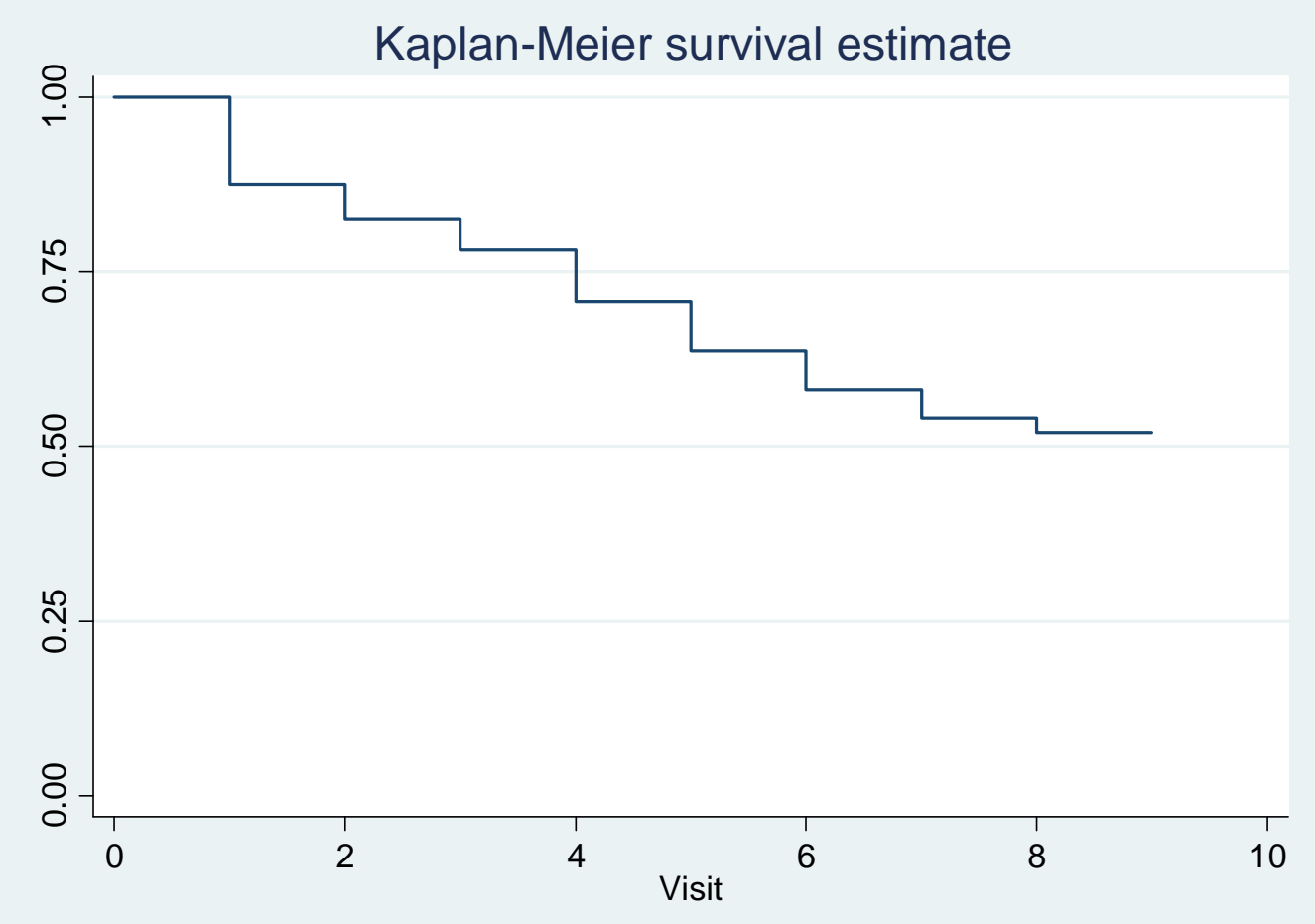


Figure 4: Kaplan-Meier Survival Estimates Selected Compliance Categories
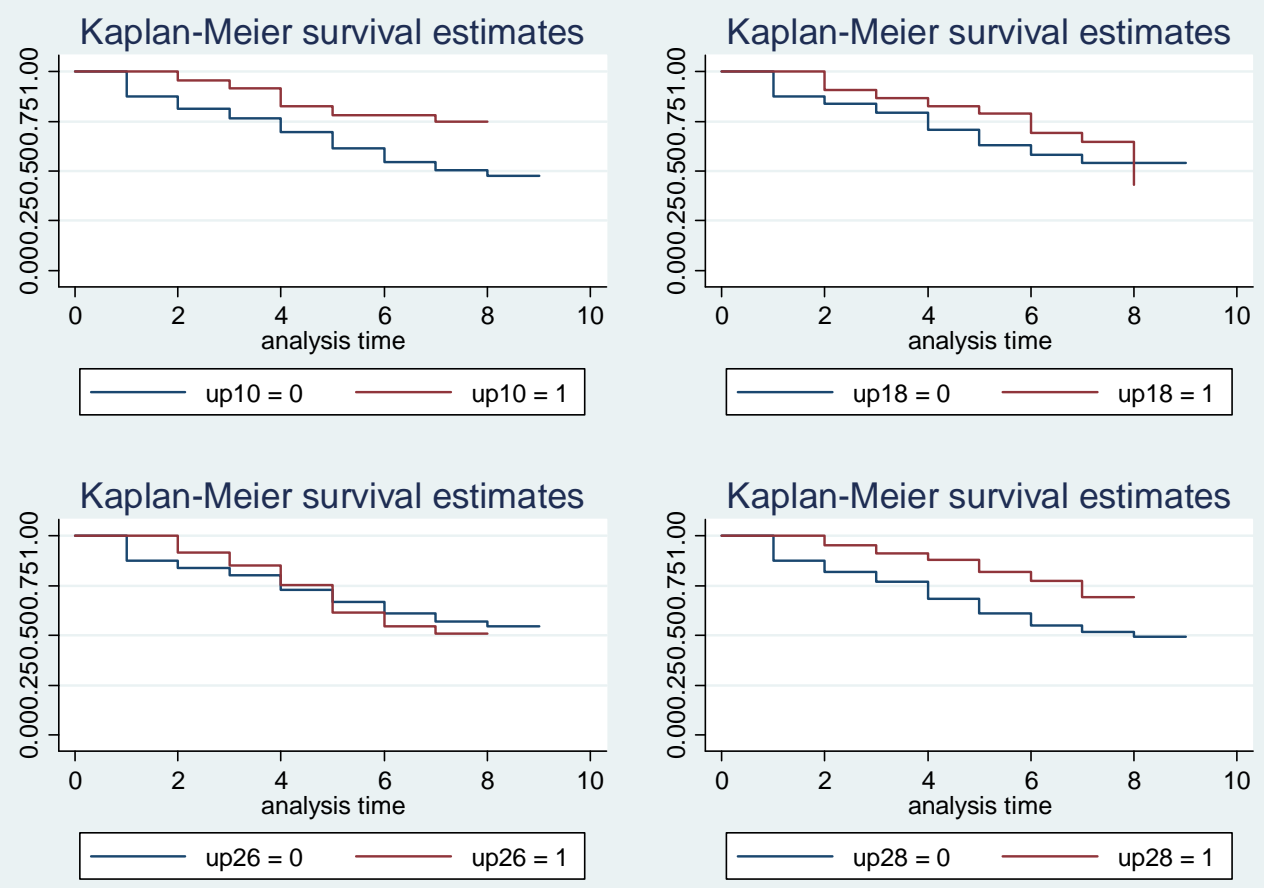
Figure 5: Change in Employment by Second Visit Improvement Group: Compensation

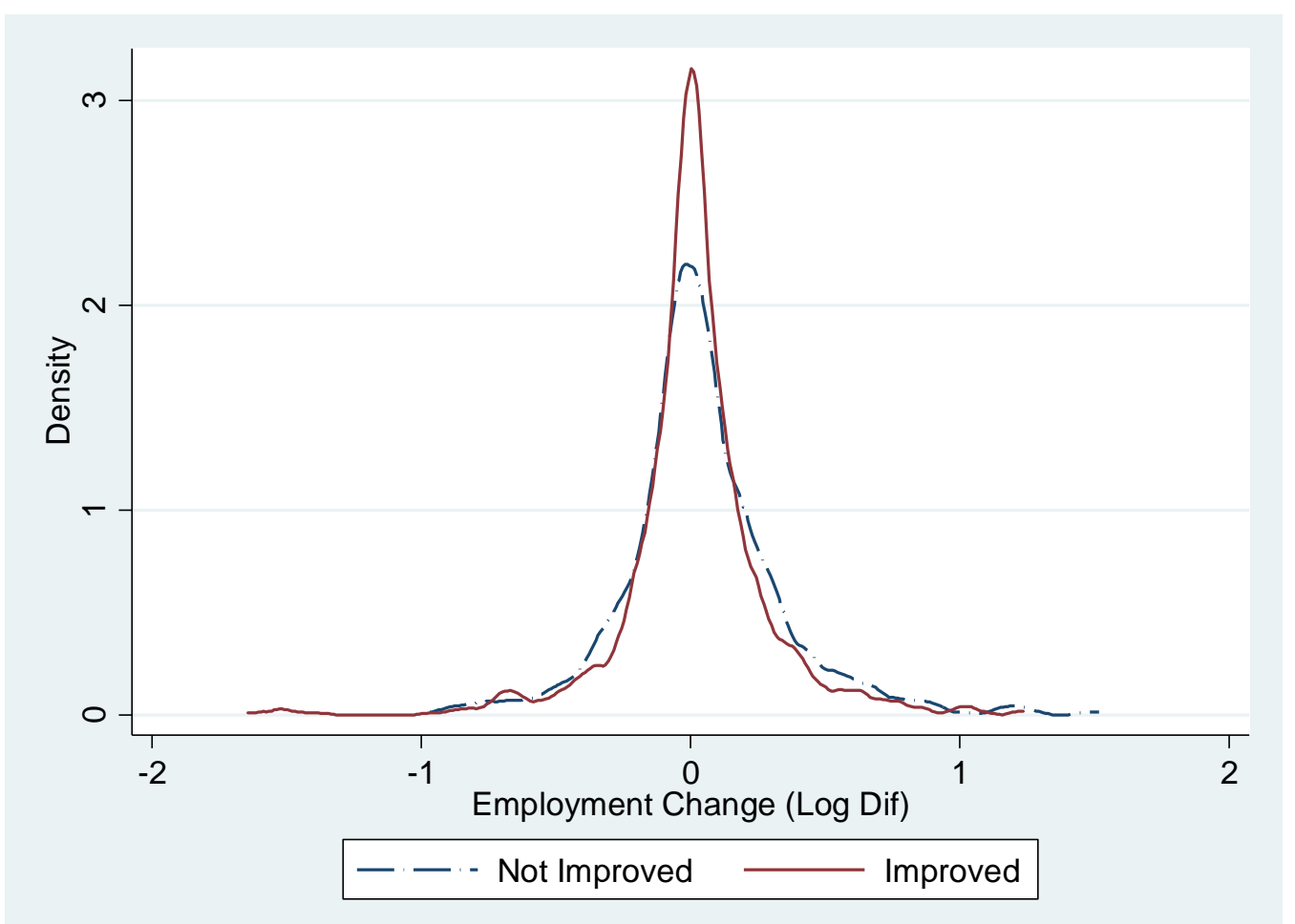

Notes: Compensation working conditions are defined in Table 5. The distributions are the kernel density estimates of the visit-to-visit difference in log employment. 
Table 1: Factory Visits by Year

\begin{tabular}{|c|c|c|c|c|c|c|c|c|c|c|}
\hline \multirow[b]{2}{*}{ Visit } & \multicolumn{10}{|c|}{ Visit Year } \\
\hline & $\underline{2001}$ & $\underline{2002}$ & $\underline{2005}$ & $\underline{2006}$ & $\underline{2007}$ & 2008 & $\underline{2009}$ & $\underline{2010}$ & $\underline{2011}$ & Total \\
\hline 1 & 85 & 34 & 7 & 188 & 30 & 37 & 27 & 20 & 18 & 446 \\
\hline 2 & 0 & 0 & 18 & 122 & 136 & 34 & 28 & 16 & 6 & 360 \\
\hline 3 & 0 & 0 & 0 & 48 & 186 & 33 & 24 & 27 & 5 & 323 \\
\hline 4 & 0 & 0 & 0 & 0 & 80 & 152 & 27 & 20 & 11 & 290 \\
\hline 5 & 0 & 0 & 0 & 0 & 11 & 112 & 82 & 24 & 12 & 241 \\
\hline 6 & 0 & 0 & 0 & 0 & 0 & 38 & 102 & 42 & 12 & 194 \\
\hline 7 & 0 & 0 & 0 & 0 & 0 & 0 & 52 & 75 & 20 & 147 \\
\hline 8 & 0 & 0 & 0 & 0 & 0 & 0 & 11 & 43 & 28 & 82 \\
\hline 9 & 0 & 0 & 0 & 0 & 0 & 0 & 0 & 13 & 12 & 25 \\
\hline 10 & 0 & 0 & 0 & 0 & 0 & 0 & 0 & 3 & 2 & 5 \\
\hline Total & 85 & 34 & 25 & 358 & 443 & 406 & 353 & 283 & 126 & 2,113 \\
\hline
\end{tabular}


Table 2: Operating Status by Country of Ownership

\begin{tabular}{|c|c|c|c|c|}
\hline \multirow[b]{2}{*}{ Ownership } & \multicolumn{2}{|c|}{ Status } & \multirow[b]{2}{*}{ Total } & \multirow[b]{2}{*}{ Close Rate } \\
\hline & Open & Closed & & \\
\hline American Samoa & 0 & 1 & 1 & $100.00 \%$ \\
\hline Australia & 3 & 1 & 4 & $25.00 \%$ \\
\hline Bangladesh & 1 & 0 & 1 & $0.00 \%$ \\
\hline Cambodia & 11 & 15 & 26 & $57.69 \%$ \\
\hline Canada & 0 & 1 & 1 & $100.00 \%$ \\
\hline China & 41 & 26 & 67 & $38.81 \%$ \\
\hline Hong Kong SAR & 37 & 40 & 77 & $51.95 \%$ \\
\hline Indonesia & 0 & 2 & 2 & $100.00 \%$ \\
\hline Korea & 29 & 12 & 41 & $29.27 \%$ \\
\hline Macau SAR & 0 & 1 & 1 & $100.00 \%$ \\
\hline Malaysia & 11 & 8 & 19 & $42.11 \%$ \\
\hline Philippines & 1 & 0 & 1 & $0.00 \%$ \\
\hline Singapore & 10 & 5 & 15 & $33.33 \%$ \\
\hline Taiwan & 61 & 28 & 89 & $31.46 \%$ \\
\hline Thailand & 1 & 0 & 1 & $0.00 \%$ \\
\hline United Kingdom & 1 & 1 & 2 & $50.00 \%$ \\
\hline United States & 3 & 1 & 4 & $25.00 \%$ \\
\hline Viet Nam & 0 & 1 & 1 & $100.00 \%$ \\
\hline Total & 213 & 149 & 362 & $41.2 \%$ \\
\hline \multicolumn{5}{|c|}{$\begin{array}{l}\text { Notes: SAR denotes Special Administrative Region. Pursuant to an agreement signed by China } \\
\text { and the UK on } 19 \text { December 1984, Hong Kong became the Hong Kong Special Administrative } \\
\text { Region (SAR) of the People's Republic of China on } 1 \text { July 1997. Macau became Macau SAR } 20 \\
\text { December 1999. There are } 9 \text { factories (3 open, } 6 \text { closed) of unknown ownership that are not } \\
\text { included in the table. }\end{array}$} \\
\hline
\end{tabular}


Table 3: Working Conditions Categories and Summary Statistics

\section{Category}

1 Child Labor

2 Discrimination

3 Forced Labor

4 Collective Agreements

5 Strikes

6 Shop Stewards

7 Liaison Officer

8 Unions

9 Information About Wages

10 Payment of Wages

11 Contracts/Hiring

12 Termination

13 Discipline

14 Sexual Harassment

15 Disputes

16 Internal Regulations

17 Health/First Aid

18 Machine Safety

19 Temperature/Ventilation/Noise/Light

20 Drinking Water

21 Sanitation

22 Food

23 Workplace Operations

24 OSH Assessment/Recording/Reporting

25 Chemicals

26 Emergency Preparedness

27 Overtime

28 Regular Hours/Weekly Rest

29 Accidents/Illnesses Compensation

30 Holidays/Annual/Special Leave

31 Maternity Benefits
First Visit First Change

$0.792 \quad-0.041$

$0.962 \quad-0.002$

$0.997 \quad 0.004$

$0.924 \quad 0.017$

$0.979 \quad 0.020$

$0.592 \quad 0.109$

$0.652 \quad 0.197$

$0.953 \quad 0.031$

$0.644 \quad 0.093$

$0.784 \quad 0.036$

$0.836 \quad 0.012$

$0.888 \quad 0.010$

$0.870 \quad 0.039$

$0.986 \quad 0.003$

$0.947 \quad 0.011$

$0.905 \quad 0.043$

$0.603 \quad 0.092$

$0.857 \quad 0.025$

$0.767 \quad 0.007$

$0.883 \quad 0.005$

$0.779 \quad 0.065$

$0.792 \quad 0.011$

$0.720 \quad 0.042$

$0.591 \quad 0.153$

$0.769-0.021$

$0.876 \quad 0.028$

$0.618 \quad 0.063$

$0.781 \quad 0.074$

$0.849 \quad 0.116$

$0.861 \quad 0.014$

$0.759 \quad 0.088$

Notes: First-visit values are the averages first across all sub-questions in each category for each factory and then averaged across all factories. The second column is the average change in this average value across all factories between the first and second visits. 
Table 4: Factor Analysis Results

Variable

Collective Agreements

Strikes

Shop Stewards

Liaison Officer

Unions

Information About Wages

Payment of Wages

Contracts/Hiring

Termination

Discipline

Sexual Harassment

Disputes

Internal Regulations

Health/First Aid

Machine Safety

Temperature/Ventilation

Drinking Water

Sanitation

Food

Workplace Operations

OSH Assessment/Recordin

Chemicals

Emergency Preparedness

Overtime

Regular Hours/Weekly Re

Accidents/IIlnesses Com

Holidays/Annual/Special

Maternity Benefits

\begin{tabular}{|c|c|c|c|c|c|c|c|c|}
\hline Factor 1 & Factor2 & Factor3 & Factor4 & Factor5 & Factor6 & Factor7 & Factor8 & Factor9 \\
\hline 0.115 & 0.196 & 0.085 & 0.229 & 0.058 & 0.063 & 0.287 & 0.078 & 0.040 \\
\hline 0.029 & 0.003 & -0.014 & -0.050 & 0.300 & 0.009 & 0.005 & 0.058 & -0.054 \\
\hline 0.193 & -0.034 & 0.040 & 0.064 & 0.063 & 0.003 & -0.039 & -0.234 & -0.032 \\
\hline 0.297 & 0.239 & 0.155 & 0.287 & 0.065 & 0.146 & 0.283 & 0.020 & 0.005 \\
\hline 0.050 & 0.119 & -0.009 & 0.100 & 0.387 & 0.013 & 0.017 & -0.071 & -0.029 \\
\hline 0.233 & 0.392 & 0.149 & 0.318 & 0.056 & 0.129 & -0.044 & 0.016 & 0.054 \\
\hline 0.271 & 0.391 & 0.241 & 0.395 & -0.001 & 0.067 & 0.022 & 0.008 & 0.064 \\
\hline 0.318 & 0.287 & 0.285 & 0.497 & 0.023 & 0.010 & 0.056 & 0.031 & -0.007 \\
\hline 0.148 & 0.301 & 0.161 & 0.219 & 0.018 & 0.019 & -0.037 & -0.050 & 0.013 \\
\hline 0.146 & 0.440 & 0.150 & 0.230 & 0.051 & -0.059 & 0.132 & -0.048 & 0.069 \\
\hline 0.019 & 0.099 & -0.011 & -0.013 & -0.030 & -0.058 & 0.091 & 0.024 & 0.053 \\
\hline 0.147 & 0.084 & 0.071 & 0.151 & 0.342 & -0.041 & 0.048 & 0.025 & 0.105 \\
\hline 0.204 & 0.258 & 0.134 & 0.329 & -0.036 & 0.143 & 0.117 & 0.240 & -0.060 \\
\hline 0.769 & 0.194 & 0.300 & 0.213 & 0.027 & 0.092 & 0.030 & 0.010 & 0.031 \\
\hline 0.303 & 0.189 & 0.506 & 0.284 & -0.002 & 0.205 & 0.023 & -0.025 & -0.032 \\
\hline 0.247 & 0.123 & 0.627 & 0.086 & 0.005 & -0.010 & -0.024 & 0.057 & 0.003 \\
\hline 0.315 & 0.230 & 0.338 & 0.198 & -0.010 & 0.048 & 0.034 & -0.020 & 0.196 \\
\hline 0.321 & 0.223 & 0.467 & 0.235 & 0.056 & 0.044 & 0.071 & -0.031 & 0.200 \\
\hline 0.691 & 0.118 & 0.150 & 0.033 & 0.023 & -0.093 & -0.016 & -0.005 & -0.024 \\
\hline 0.308 & 0.153 & 0.630 & 0.115 & 0.004 & -0.034 & 0.038 & -0.035 & -0.037 \\
\hline 0.440 & 0.230 & 0.227 & 0.323 & -0.016 & 0.273 & 0.159 & -0.033 & -0.012 \\
\hline 0.102 & 0.072 & 0.086 & -0.033 & -0.036 & 0.018 & -0.047 & -0.037 & -0.077 \\
\hline 0.321 & 0.138 & 0.416 & 0.262 & -0.012 & 0.336 & 0.045 & 0.064 & 0.035 \\
\hline 0.217 & 0.673 & 0.166 & 0.177 & 0.061 & 0.036 & 0.023 & -0.024 & 0.017 \\
\hline 0.183 & 0.607 & 0.146 & 0.113 & -0.047 & 0.047 & 0.014 & 0.072 & -0.028 \\
\hline 0.094 & 0.221 & 0.137 & 0.375 & 0.101 & 0.064 & 0.055 & -0.003 & 0.089 \\
\hline 0.264 & 0.430 & 0.234 & 0.491 & 0.079 & -0.021 & 0.081 & 0.013 & 0.014 \\
\hline 0.325 & 0.217 & 0.232 & 0.507 & 0.019 & 0.077 & -0.037 & -0.048 & 0.017 \\
\hline
\end{tabular}

Notes: Principle factor method used to analyze the correlation matrix. Communality estimated with squared multiple correlations. Orthogonal rotation applied. Principle

Components factor analysis not used because the mean value of resulting uniqueness is over 0.65 . Maximum values in bold. 
Table 5: Groupings Resulting from Factor Analysis

Group 1: Communication and Workplace Systems

6 Shop Stewards

7 Liaison Officer

23 Workplace Operations

Group 2: Occupational Safety and Health

17 Health/First Aid

18 Machine Safety

19 Temperature/Ventilation

20 Drinking Water

21 Sanitation

22 Food

24 OSH Assessment/Recording

25 Chemicals

26 Emergency Preparedness

Group 3: Modern HR Practices

9 Information About Wages

12 Termination

13 Discipline

27 Overtime

28 Regular Hours/Weekly Rest
Group 4: Compensation

10 Payment of Wages

11 Contracts/Hiring

16 Internal Regulations

29 Accidents/IIInesses Com

30 Holidays/Annual/Special

31 Maternity Benefits

Group 5: Unions

4 Collective Agreements

5 Strikes

8 Unions

14 Sexual Harassment

15 Disputes

Group 6: Core Labor Standards

1 Child Labor

2 Discrimination

3 Forced Labor 
Table 6: Compliance Groups and Closure Probabilities

\begin{tabular}{|c|c|c|c|c|}
\hline VARIABLES & $\begin{array}{c}\text { (1) } \\
\text { Levels }\end{array}$ & $\begin{array}{c}\text { (2) } \\
\text { Differences }\end{array}$ & $\begin{array}{c}(3) \\
\text { Visit } 2 \text { Change }\end{array}$ & $\begin{array}{c}(4) \\
\text { Visit } 2 \text { Change } \\
\text { Indicator }\end{array}$ \\
\hline Communication & $\begin{array}{c}-1.512 * * \\
(0.638)\end{array}$ & $\begin{array}{l}-0.235 \\
(0.967)\end{array}$ & $\begin{array}{c}0.143 \\
(0.682)\end{array}$ & $\begin{array}{c}-0.507^{* * * *} \\
(0.185)\end{array}$ \\
\hline $\mathrm{OSH}$ & $\begin{array}{l}-2.018^{*} \\
(1.112)\end{array}$ & $\begin{array}{l}-0.467 \\
(1.745)\end{array}$ & $\begin{array}{l}-1.626 \\
(1.468)\end{array}$ & $\begin{array}{l}-0.229 \\
(0.195)\end{array}$ \\
\hline Modern HR & $\begin{array}{l}-0.720 \\
(0.956)\end{array}$ & $\begin{array}{l}-1.262 \\
(1.395)\end{array}$ & $\begin{array}{l}-1.025 \\
(1.097)\end{array}$ & $\begin{array}{c}-0.459 * * \\
(0.191)\end{array}$ \\
\hline Compensation & $\begin{array}{l}2.057^{*} \\
(1.057)\end{array}$ & $\begin{array}{l}-2.829 \\
(1.885)\end{array}$ & $\begin{array}{l}-2.828^{*} \\
(1.507)\end{array}$ & $\begin{array}{c}-0.541 * * * \\
(0.192)\end{array}$ \\
\hline Unions & $\begin{array}{l}-0.712 \\
(1.191)\end{array}$ & $\begin{array}{c}2.202 \\
(2.082)\end{array}$ & $\begin{array}{l}-0.841 \\
(1.820)\end{array}$ & $\begin{array}{l}-0.085 \\
(0.196)\end{array}$ \\
\hline RS Buyer & $\begin{array}{c}-0.957 * * * \\
(0.213)\end{array}$ & $\begin{array}{l}-0.431^{*} \\
(0.240)\end{array}$ & $\begin{array}{c}-1.086^{* * *} \\
(0.215)\end{array}$ & $\begin{array}{c}-1.006^{* * * *} \\
(0.212)\end{array}$ \\
\hline Owned: Anglo & $\begin{array}{l}-0.106 \\
(0.304)\end{array}$ & $\begin{array}{l}-0.278 \\
(0.374)\end{array}$ & $\begin{array}{l}-0.062 \\
(0.305)\end{array}$ & $\begin{array}{l}-0.194 \\
(0.314)\end{array}$ \\
\hline Owned: Korea & $\begin{array}{l}-0.351 \\
(0.397)\end{array}$ & $\begin{array}{l}-0.257 \\
(0.459)\end{array}$ & $\begin{array}{l}-0.426 \\
(0.402)\end{array}$ & $\begin{array}{l}-0.396 \\
(0.406)\end{array}$ \\
\hline Owned: China & $\begin{array}{l}-0.222 \\
(0.295)\end{array}$ & $\begin{array}{l}-0.407 \\
(0.362)\end{array}$ & $\begin{array}{l}-0.217 \\
(0.306)\end{array}$ & $\begin{array}{l}-0.283 \\
(0.307)\end{array}$ \\
\hline Owned: Other Asia & $\begin{array}{l}-0.180 \\
(0.372)\end{array}$ & $\begin{array}{l}-0.249 \\
(0.422)\end{array}$ & $\begin{array}{l}-0.267 \\
(0.372)\end{array}$ & $\begin{array}{l}-0.100 \\
(0.385)\end{array}$ \\
\hline Owned: Other & $\begin{array}{l}0.790^{*} \\
(0.460)\end{array}$ & $\begin{array}{l}-0.065 \\
(0.685)\end{array}$ & $\begin{array}{l}1.059 * * \\
(0.459)\end{array}$ & $\begin{array}{l}0.890^{*} \\
(0.461)\end{array}$ \\
\hline Log Emp & $\begin{array}{l}-0.236^{*} \\
(0.122)\end{array}$ & $\begin{array}{c}-0.376^{* *} \\
(0.148)\end{array}$ & $\begin{array}{c}-0.288 * * * \\
(0.110)\end{array}$ & $\begin{array}{c}-0.267 * * \\
(0.112)\end{array}$ \\
\hline Crisis $=1$ & $\begin{array}{c}1.836 * * * \\
(0.188)\end{array}$ & $\begin{array}{c}3.535 * * * \\
(0.344)\end{array}$ & $\begin{array}{c}1.865^{* * * *} \\
(0.186)\end{array}$ & $\begin{array}{c}1.923 * * * \\
(0.189)\end{array}$ \\
\hline Recovery=1 & $\begin{array}{c}1.737 * * * \\
(0.245)\end{array}$ & $\begin{array}{c}3.181 * * * \\
(0.376)\end{array}$ & $\begin{array}{c}1.692 * * * \\
(0.244)\end{array}$ & $\begin{array}{c}1.767 * * * \\
(0.246)\end{array}$ \\
\hline Constant & $\begin{array}{c}0.979 \\
(1.398)\end{array}$ & $\begin{array}{l}-1.578 \\
(1.024)\end{array}$ & $\begin{array}{l}-0.466 \\
(0.733)\end{array}$ & $\begin{array}{c}0.096 \\
(0.743)\end{array}$ \\
\hline Observations & 1,821 & 1,410 & 1,822 & 1,822 \\
\hline
\end{tabular}


Table 7: Aggregate Foreign Ownership

\begin{tabular}{|c|c|c|c|c|}
\hline VARIABLES & $\begin{array}{c}(1) \\
\text { Levels }\end{array}$ & $\begin{array}{c}(2) \\
\text { Differences }\end{array}$ & $\begin{array}{c}\text { (3) } \\
\text { Visit } 2 \text { Change }\end{array}$ & $\begin{array}{c}(4) \\
\text { Visit } 2 \text { Change } \\
\text { Indicator }\end{array}$ \\
\hline Communication & $\begin{array}{c}-1.631 * * \\
(0.638)\end{array}$ & $\begin{array}{c}-0.238 \\
(0.963)\end{array}$ & $\begin{array}{c}0.277 \\
(0.665)\end{array}$ & $\begin{array}{c}-0.510 * * * \\
(0.187)\end{array}$ \\
\hline $\mathrm{OSH}$ & $\begin{array}{c}-2.094^{*} \\
(1.119)\end{array}$ & $\begin{array}{c}-0.391 \\
(1.730)\end{array}$ & $\begin{array}{l}-1.293 \\
(1.449)\end{array}$ & $\begin{array}{c}-0.220 \\
(0.195)\end{array}$ \\
\hline Modern HR & $\begin{array}{l}-0.704 \\
(0.958)\end{array}$ & $\begin{array}{l}-1.305 \\
(1.382)\end{array}$ & $\begin{array}{l}-1.343 \\
(1.070)\end{array}$ & $\begin{array}{c}-0.533 * * * \\
(0.186)\end{array}$ \\
\hline Compensation & $\begin{array}{c}2.326^{* * *} \\
(1.057)\end{array}$ & $\begin{array}{l}-2.708 \\
(1.864)\end{array}$ & $\begin{array}{l}-2.685^{*} \\
(1.514)\end{array}$ & $\begin{array}{c}-0.502 * * * \\
(0.189)\end{array}$ \\
\hline Unions & $\begin{array}{l}-1.107 \\
(1.261)\end{array}$ & $\begin{array}{c}2.172 \\
(2.083)\end{array}$ & $\begin{array}{c}-0.928 \\
(1.815)\end{array}$ & $\begin{array}{l}-0.052 \\
(0.195)\end{array}$ \\
\hline RS Buyer & $\begin{array}{c}-0.934 * * * \\
(0.209)\end{array}$ & $\begin{array}{c}-0.408^{*} \\
(0.235)\end{array}$ & $\begin{array}{c}-1.058^{* * *} \\
(0.212)\end{array}$ & $\begin{array}{c}-0.954 * * * \\
(0.208)\end{array}$ \\
\hline Foreign & $\begin{array}{c}0.166 \\
(0.279)\end{array}$ & $\begin{array}{c}0.327 \\
(0.340)\end{array}$ & $\begin{array}{c}0.144 \\
(0.285)\end{array}$ & $\begin{array}{c}0.200 \\
(0.291)\end{array}$ \\
\hline Log Emp & $\begin{array}{c}-0.218^{*} \\
(0.122)\end{array}$ & $\begin{array}{c}-0.361^{* *} \\
(0.146)\end{array}$ & $\begin{array}{c}-0.269 * * \\
(0.109)\end{array}$ & $\begin{array}{c}-0.248^{* *} \\
(0.112)\end{array}$ \\
\hline Crisis $=1$ & $\begin{array}{c}1.821 * * * \\
(0.184)\end{array}$ & $\begin{array}{c}3.559 * * * \\
(0.342)\end{array}$ & $\begin{array}{c}1.854 * * * \\
(0.183)\end{array}$ & $\begin{array}{c}1.928 * * * \\
(0.186)\end{array}$ \\
\hline Recovery=1 & $\begin{array}{c}1.763 * * * \\
(0.243)\end{array}$ & $\begin{array}{c}3.185 * * * \\
(0.373)\end{array}$ & $\begin{array}{c}1.736^{* * * *} \\
(0.243)\end{array}$ & $\begin{array}{c}1.805 * * * \\
(0.245)\end{array}$ \\
\hline Constant & $\begin{array}{c}0.985 \\
(1.443)\end{array}$ & $\begin{array}{c}-2.019 * * \\
(0.965)\end{array}$ & $\begin{array}{l}-0.760 \\
(0.695)\end{array}$ & $\begin{array}{c}-0.243 \\
(0.716)\end{array}$ \\
\hline Observations & 1,821 & 1,410 & 1,822 & 1,822 \\
\hline
\end{tabular}

Notes: Standard errors in parentheses. ${ }^{* * *} p<0.01,{ }^{* *} p<0.05,{ }^{*} p<0.1$. "National Factories" is the number of factories in the sample with the same national ownership. 
Table 8: National External Economies

\begin{tabular}{|c|c|c|c|c|}
\hline VARIABLES & $\begin{array}{c}(1) \\
\text { Levels }\end{array}$ & $\begin{array}{c}\text { (2) } \\
\text { Differences }\end{array}$ & $\begin{array}{c}\text { (3) } \\
\text { Visit } 2 \text { Change }\end{array}$ & $\begin{array}{c}\text { (4) } \\
\text { Visit } 2 \text { Change } \\
\text { Indicator }\end{array}$ \\
\hline Communication & $\begin{array}{c}-1.675 * * * \\
(0.637)\end{array}$ & $\begin{array}{l}-0.077 \\
(0.958)\end{array}$ & $\begin{array}{c}0.197 \\
(0.660)\end{array}$ & $\begin{array}{c}-0.556 * * * \\
(0.183)\end{array}$ \\
\hline $\mathrm{OSH}$ & $\begin{array}{c}-2.023^{*} \\
(1.115)\end{array}$ & $\begin{array}{c}-0.602 \\
(1.759)\end{array}$ & $\begin{array}{l}-1.439 \\
(1.454)\end{array}$ & $\begin{array}{l}-0.227 \\
(0.190)\end{array}$ \\
\hline Modern HR & $\begin{array}{c}-0.858 \\
(0.965)\end{array}$ & $\begin{array}{c}-1.146 \\
(1.414)\end{array}$ & $\begin{array}{l}-1.171 \\
(1.067)\end{array}$ & $\begin{array}{c}-0.526 * * * \\
(0.185)\end{array}$ \\
\hline Compensation & $\begin{array}{c}2.216^{* * *} \\
(1.072)\end{array}$ & $\begin{array}{l}-2.912 \\
(1.915)\end{array}$ & $\begin{array}{l}-2.708^{*} \\
(1.510)\end{array}$ & $\begin{array}{c}-0.511 * * * \\
(0.189)\end{array}$ \\
\hline Unions & $\begin{array}{l}-1.025 \\
(1.221)\end{array}$ & $\begin{array}{c}2.423 \\
(2.103)\end{array}$ & $\begin{array}{l}-0.933 \\
(1.813)\end{array}$ & $\begin{array}{c}-0.066 \\
(0.194)\end{array}$ \\
\hline RS Buyer & $\begin{array}{c}-0.981 * * * \\
(0.211)\end{array}$ & $\begin{array}{c}-0.500 * * \\
(0.235)\end{array}$ & $\begin{array}{c}-1.087 * * * \\
(0.211)\end{array}$ & $\begin{array}{c}-1.004 * * * \\
(0.209)\end{array}$ \\
\hline National Factories & $\begin{array}{c}-0.003 * * \\
(0.001)\end{array}$ & $\begin{array}{c}-0.005^{* *} \\
(0.002)\end{array}$ & $\begin{array}{l}-0.002 \\
(0.001)\end{array}$ & $\begin{array}{c}-0.003 * * \\
(0.001)\end{array}$ \\
\hline Log Emp & $\begin{array}{c}-0.235^{*} \\
(0.122)\end{array}$ & $\begin{array}{c}-0.403 * * * \\
(0.147)\end{array}$ & $\begin{array}{c}-0.284 * * * \\
(0.109)\end{array}$ & $\begin{array}{c}-0.276^{* *} \\
(0.111)\end{array}$ \\
\hline Crisis $=1$ & $\begin{array}{c}1.805 * * * \\
(0.184)\end{array}$ & $\begin{array}{c}3.542 * * * \\
(0.342)\end{array}$ & $\begin{array}{c}1.843 * * * \\
(0.183)\end{array}$ & $\begin{array}{c}1.913 * * * \\
(0.186)\end{array}$ \\
\hline Recovery=1 & $\begin{array}{c}1.780 * * * \\
(0.243)\end{array}$ & $\begin{array}{c}3.206^{* * *} * \\
(0.373)\end{array}$ & $\begin{array}{c}1.743 * * * \\
(0.242)\end{array}$ & $\begin{array}{c}1.815^{* * *} * \\
(0.245)\end{array}$ \\
\hline Constant & $\begin{array}{c}1.504 \\
(1.426)\end{array}$ & $\begin{array}{c}-1.268 \\
(1.003)\end{array}$ & $\begin{array}{l}-0.457 \\
(0.718)\end{array}$ & $\begin{array}{c}0.293 \\
(0.740)\end{array}$ \\
\hline Observations & 1,821 & 1,410 & 1,822 & 1,822 \\
\hline
\end{tabular}

Notes: Standard errors in parentheses. ${ }^{* *} p<0.01,{ }^{* *} p<0.05,{ }^{*} p<0.1$. "National Factories" is the number of factories in the sample with the same national ownership. 
Table 9: Omitting the Crisis

\begin{tabular}{|c|c|c|c|c|}
\hline VARIABLES & $\begin{array}{c}\text { (1) } \\
\text { Levels }\end{array}$ & $\begin{array}{c}\text { (2) } \\
\text { Differences }\end{array}$ & $\begin{array}{c}\text { (3) } \\
\text { Visit } 2 \text { Change }\end{array}$ & $\begin{array}{c}\text { (4) } \\
\text { Visit } 2 \text { Change } \\
\text { Indicator }\end{array}$ \\
\hline Communication & $\begin{array}{c}-3.775^{* * * *} \\
(0.841)\end{array}$ & $\begin{array}{c}1.069 \\
(1.265)\end{array}$ & $\begin{array}{c}0.168 \\
(1.027)\end{array}$ & $\begin{array}{c}-1.064 * * * \\
(0.278)\end{array}$ \\
\hline $\mathrm{OSH}$ & $\begin{array}{l}-1.386 \\
(1.331)\end{array}$ & $\begin{array}{c}2.772 \\
(2.414)\end{array}$ & $\begin{array}{l}-3.889 \\
(2.680)\end{array}$ & $\begin{array}{c}-0.414 \\
(0.294)\end{array}$ \\
\hline Modern HR & $\begin{array}{c}0.135 \\
(1.194)\end{array}$ & $\begin{array}{c}1.707 \\
(2.184)\end{array}$ & $\begin{array}{l}-1.500 \\
(1.671)\end{array}$ & $\begin{array}{c}-0.646^{* *} \\
(0.291)\end{array}$ \\
\hline Compensation & $\begin{array}{c}1.062 \\
(1.367)\end{array}$ & $\begin{array}{l}-5.067 \\
(3.199)\end{array}$ & $\begin{array}{l}-4.916^{*} \\
(2.564)\end{array}$ & $\begin{array}{c}-0.867 * * * \\
(0.323)\end{array}$ \\
\hline Unions & $\begin{array}{l}-1.374 \\
(1.234)\end{array}$ & $\begin{array}{c}2.999 \\
(2.763)\end{array}$ & $\begin{array}{l}-0.708 \\
(2.410)\end{array}$ & $\begin{array}{c}-0.092 \\
(0.329)\end{array}$ \\
\hline RS Buyer & $\begin{array}{c}-1.394 * * * \\
(0.301)\end{array}$ & $\begin{array}{c}-0.663^{*} \\
(0.381)\end{array}$ & $\begin{array}{c}-1.667 * * * \\
(0.296)\end{array}$ & $\begin{array}{c}-1.609 * * * \\
(0.297)\end{array}$ \\
\hline Foreign & $\begin{array}{c}0.250 \\
(0.364)\end{array}$ & $\begin{array}{c}0.663 \\
(0.506)\end{array}$ & $\begin{array}{c}0.340 \\
(0.393)\end{array}$ & $\begin{array}{c}0.155 \\
(0.366)\end{array}$ \\
\hline Log Emp & $\begin{array}{l}-0.117 \\
(0.166)\end{array}$ & $\begin{array}{l}-0.412 \\
(0.267)\end{array}$ & $\begin{array}{c}-0.246^{*} \\
(0.134)\end{array}$ & $\begin{array}{l}-0.180 \\
(0.138)\end{array}$ \\
\hline Recovery=1 & $\begin{array}{c}1.892 * * * \\
(0.254)\end{array}$ & $\begin{array}{c}3.207 * * * \\
(0.378)\end{array}$ & $\begin{array}{c}1.776 * * * \\
(0.255)\end{array}$ & $\begin{array}{c}2.113 * * * \\
(0.265)\end{array}$ \\
\hline Constant & $\begin{array}{c}1.915 \\
(1.568)\end{array}$ & $\begin{array}{l}-1.808 \\
(1.697)\end{array}$ & $\begin{array}{l}-0.590 \\
(0.857)\end{array}$ & $\begin{array}{l}-0.091 \\
(0.885)\end{array}$ \\
\hline Observations & 1,550 & 1,214 & 1,551 & 1,551 \\
\hline
\end{tabular}

Notes: Standard errors in parentheses. ${ }^{* * *} p<0.01,{ }^{* *} p<0.05,{ }^{*} p<0.1$. "National Factories" is the number of factories in the sample with the same national ownership. 
Table 10: Controlling for Initial Compliance

\begin{tabular}{|c|c|c|c|c|}
\hline VARIABLES & $\begin{array}{c}\text { (1) } \\
\text { Levels }\end{array}$ & $\begin{array}{c}\text { (2) } \\
\text { Differences }\end{array}$ & $\begin{array}{c}(3) \\
\text { Visit } 2 \text { Change }\end{array}$ & $\begin{array}{c}(4) \\
\text { Visit } 2 \text { Change } \\
\text { Indicator }\end{array}$ \\
\hline Communication & $\begin{array}{c}-1.631 * * \\
(0.638)\end{array}$ & $\begin{array}{c}-0.248 \\
(1.065)\end{array}$ & $\begin{array}{l}-0.718 \\
(0.707)\end{array}$ & $\begin{array}{c}-0.511 * * * \\
(0.195)\end{array}$ \\
\hline $\mathrm{OSH}$ & $\begin{array}{l}-2.094^{*} \\
(1.119)\end{array}$ & $\begin{array}{c}0.054 \\
(1.940)\end{array}$ & $\begin{array}{l}-1.801 \\
(1.457)\end{array}$ & $\begin{array}{c}-0.196 \\
(0.201)\end{array}$ \\
\hline Modern HR & $\begin{array}{l}-0.704 \\
(0.958)\end{array}$ & $\begin{array}{c}-0.685 \\
(1.543)\end{array}$ & $\begin{array}{l}-1.313 \\
(1.103)\end{array}$ & $\begin{array}{c}-0.535^{* * *} \\
(0.194)\end{array}$ \\
\hline Compensation & $\begin{array}{c}2.326^{* *} \\
(1.057)\end{array}$ & $\begin{array}{l}-3.752 * \\
(2.092)\end{array}$ & $\begin{array}{l}-1.791 \\
(1.596)\end{array}$ & $\begin{array}{l}-0.388^{*} \\
(0.199)\end{array}$ \\
\hline Unions & $\begin{array}{l}-1.107 \\
(1.261)\end{array}$ & $\begin{array}{c}1.561 \\
(2.382)\end{array}$ & $\begin{array}{l}-1.308 \\
(1.906)\end{array}$ & $\begin{array}{l}-0.122 \\
(0.201)\end{array}$ \\
\hline RS Buyer & $\begin{array}{c}-0.934 * * * \\
(0.209)\end{array}$ & $\begin{array}{c}-0.477 * * \\
(0.242)\end{array}$ & $\begin{array}{c}-0.835^{* * *} \\
(0.218)\end{array}$ & $\begin{array}{c}-0.842 * * * \\
(0.213)\end{array}$ \\
\hline Foreign & $\begin{array}{c}0.166 \\
(0.279)\end{array}$ & $\begin{array}{c}0.343 \\
(0.355)\end{array}$ & $\begin{array}{l}-0.040 \\
(0.292)\end{array}$ & $\begin{array}{c}0.065 \\
(0.298)\end{array}$ \\
\hline Log Emp & $\begin{array}{c}-0.218^{*} \\
(0.122)\end{array}$ & $\begin{array}{c}-0.434 * * * \\
(0.157)\end{array}$ & $\begin{array}{c}-0.204^{*} \\
(0.117)\end{array}$ & $\begin{array}{c}-0.199^{*} \\
(0.119)\end{array}$ \\
\hline Crisis $=1$ & $\begin{array}{c}1.821 * * * \\
(0.184)\end{array}$ & $\begin{array}{c}3.619 * * * \\
(0.346)\end{array}$ & $\begin{array}{c}1.961^{* * *} \\
(0.189)\end{array}$ & $\begin{array}{c}2.052 * * * \\
(0.195)\end{array}$ \\
\hline Recovery=1 & $\begin{array}{c}1.763 * * * \\
(0.243)\end{array}$ & $\begin{array}{c}3.286 * * * \\
(0.380)\end{array}$ & $\begin{array}{c}1.925 * * * \\
(0.250)\end{array}$ & $\begin{array}{c}1.979 * * * \\
(0.253)\end{array}$ \\
\hline Constant & $\begin{array}{c}0.985 \\
(1.443)\end{array}$ & $\begin{array}{l}-4.291 \\
(3.513)\end{array}$ & $\begin{array}{c}2.295 \\
(1.439)\end{array}$ & $\begin{array}{c}1.606 \\
(1.390)\end{array}$ \\
\hline Observations & 1,821 & 1,410 & 1,821 & 1.821 \\
\hline
\end{tabular}


Table 11: Employment Growth and Compliance

\begin{tabular}{|c|c|c|}
\hline VARIABLES & $\begin{array}{c}(1) \\
\text { Levels }\end{array}$ & $\begin{array}{c}(2) \\
\text { Differences }\end{array}$ \\
\hline Communication & $\begin{array}{l}-0.023 \\
(0.107)\end{array}$ & $\begin{array}{l}-0.007 \\
(0.015)\end{array}$ \\
\hline $\mathrm{OSH}$ & $\begin{array}{c}0.157 \\
(0.115)\end{array}$ & $\begin{array}{l}-0.012 \\
(0.016)\end{array}$ \\
\hline Modern HR & $\begin{array}{c}-0.510 * * * \\
(0.119)\end{array}$ & $\begin{array}{c}0.018 \\
(0.015)\end{array}$ \\
\hline Compensation & $\begin{array}{c}0.131 \\
(0.156)\end{array}$ & $\begin{array}{c}-0.037 * * \\
(0.016)\end{array}$ \\
\hline Unions & $\begin{array}{l}-0.043 \\
(0.219)\end{array}$ & $\begin{array}{l}-0.007 \\
(0.014)\end{array}$ \\
\hline RS Buyer & $\begin{array}{c}-0.050 * * * \\
(0.015)\end{array}$ & $\begin{array}{c}-0.052 * * * \\
(0.015)\end{array}$ \\
\hline Foreign & $\begin{array}{l}-0.058 \\
(0.095)\end{array}$ & $\begin{array}{l}-0.048 \\
(0.096)\end{array}$ \\
\hline Log Emp & $\begin{array}{c}0.068 * * * \\
(0.009)\end{array}$ & $\begin{array}{c}0.072 * * * \\
(0.009)\end{array}$ \\
\hline Crisis $=1$ & $\begin{array}{c}-0.083 * * * \\
(0.016)\end{array}$ & $\begin{array}{c}-0.090 * * * \\
(0.015)\end{array}$ \\
\hline Recovery=1 & $\begin{array}{c}0.097 * * * \\
(0.018)\end{array}$ & $\begin{array}{c}0.098 * * * \\
(0.018)\end{array}$ \\
\hline Constant & $\begin{array}{l}-0.093 \\
(0.236)\end{array}$ & $\begin{array}{c}-0.334 * * * \\
(0.118)\end{array}$ \\
\hline Observations & 1,666 & 1,666 \\
\hline R-Squared & 0.075 & 0.068 \\
\hline
\end{tabular}

